\title{
Evaluation of antidote potential of methanol leaf extract of Bauhinia monandra on heparin-induced thrombocytopenia in mice
}

\author{
Kelechi M. NWORIE ${ }^{1 *}$, Augustine N. OKORIE ${ }^{2}$, DANiel N. Ebere ${ }^{1}$, ONYEDIKACHI C. ObiKe $^{1}$ \\ ${ }^{1}$ Pharmaceutical Outcomes Research Group, Faculty of Pharmacy, University of Nigeria, Nsukka, Nigeria \\ ${ }^{2}$ Department of Pharmacology and Toxicology, University of Nigeria, Nsukka, Nigeria
}

\begin{abstract}
Thrombocytopenia is closely associated with heparin therapy and hematological disorders and other common diseases in patients admitted in the hospital. Globally, thrombocytopenic cases in hospitals leading to $80 \%$ of deaths are mainly due to refractory bleeding and lack of availability of platelet concentrates. Currently, chemical compounds for managing thrombocytopenia are needed. The aim of the study was to determine the effect of methanolic leaf extract of Bauhinia monandra as a potential antidote for treating heparin-induced thrombocytopenia (HIT). A total of 30 mice were used for the experimental study. The mice were divided into five Groups (I-V) of six mice each. Group I (normal control) was given distilled water only, and Group II (positive control) was given heparin only. Groups III, IV, and V (treatment groups) were given heparin and methanolic leaf extract of $B$. monandra at a dose of 100,200 , and $400 \mathrm{mg} / \mathrm{kg}$ body weight (b. wt), respectively. Furthermore, blood samples were collected to determine the blood platelet count. Bleeding time and clotting time were also determined. This study showed that the mice in the group treated with methanolic leaf extract of $B$. monandra at a dose of $400 \mathrm{mg} / \mathrm{kg}$ b. wt had significantly $(P<0.05)$ higher platelet counts $(225.10 \pm 6.41)$ than the control groups: normal control $(181.90 \pm 11.38)$ and positive control $(127.65 \pm 5.79)$. It also significantly decreased the bleeding and clotting time. Acute toxicity test showed no significant physical and behavioral changes. The results from this study show that leaf methanolic extract of $B$. monandra is effective as an antidote for treating HIT.
\end{abstract}

Key words: phytochemicals, Bauhinia monandra, thrombocytopenia, antidote

\section{Introduction}

Thrombocytopenia is a medical condition characterized by an abnormally low platelet count in the blood. Platelets are a component of the blood whose function is to contribute to hemostasis, the process of stopping bleeding by clumping and clotting blood vessel injuries (Balduini and Melazzini, 2017). In thrombocytopenia, the blood has lower levels of platelets, and hence mild to severe bleeding can occur. Bleeding can be internal or occur on the surface of the skin or just beneath it. The reported incidence of hemorrhagic complications in the literature ranged from $3 \%$ to $53 \%$, and the frequency of hemorrhagic deaths ranged from $14 \%$ to $24 \%$ (Kantarjian et al., 2007). Thrombocytopenia is caused by the bone marrow that cannot make enough platelets, when the body rapidly destroys blood platelets, or medication side effects (Kamthe and Kulkami, 2017). This may occur as a result of a separate disorder, such as leukemia, aplastic anemia, viral infections, genetic conditions, immune system disorders, liver failure, and dehydration. Drugs are also a common cause of acute thrombocytopenia in adults (Visentin and Liu, 2007), and most cases of druginduced thrombocytopenia (DITP) are caused by drugdependent antibodies (Warkentin et al., 2006; Ahmed et al., 2007; Warkentin et al., 2008). These antibodies are particularly specific to the drug structure and bind

\footnotetext{
* Corresponding author: Pharmaceutical Outcomes Research Group, Faculty of Pharmacy, University of Nigeria, Nsukka, Nigeria; e-mail: nworiekelechimartins@gmail.com
} 
tightly to platelets via their Fab regions in the presence of the drug (Warkentin et al., 2006; Ahmed et al., 2007; Peterson et al., 2008). DITP occurs 1-2 weeks after commencing a new drug therapy or suddenly after a single dose, when the drug has previously been administered intermittently (George and Aster, 2009). However, in severe cases, thrombocytopenia can occur immediately after administration of the first dose of an antithrombotic agent such as tirofiban, abciximab, and eptifibatide (George and Aster, 2009). Recovery from DITP usually starts within 1-3 days after stopping the drug administration and completes within a week (Peterson et al., 2008). DITPs often occur suddenly, and in severe cases may lead to major bleeding problems and death (George et al., 1998; Aster and Bougie, 2007; Aster et al., 2009).

HIT is a medical complication commonly associated with heparin therapy. It rarely occurs outside the hospital. Heparin is used in medicine for both the prevention and the treatment of arterial and venous thrombosis. In HIT, the blood platelet count falls below the normal range, which may lead to an increased risk of bleeding. Since it does not help to discontinue the anticoagulant agent in the case of thrombosis, the treatment of HIT requires stopping the heparin treatment entirely for the platelet count to return to normal within days (Watson et al., 2012) and choosing of an agent that will not reduce platelet count any further, such as danaparoid, fondaparinux, argatroban, and bivalirudin (Ortel, 2009). Although DITP is cured after several days in most cases, severe cases result in major bleeding (problems) and occasionally to death. Hence, a rapid recovery from this medical condition is a major concern for researchers. Therefore, any pharmacological agent that can rapidly and effectively reverse the blood platelet count back to the normal range in the case of HIT will be useful in the medical field. Natural plant extracts rich in phytoconstituents such as alkaloids, tannins, polyphenols, flavonoids, and other related compounds are known to possess several health benefits and to reduce the incidence of diseases (Evans and Halliwel, 2001). Therefore, a research focused on natural and herbal drugs as a potential remedy may result in significant health benefits while minimizing the adverse effects (Gowri et al., 2011).

Bauhinia monandra is a species of leguminous trees that belong to the Caesalpiniaceae family (Keay, 1989). It is an evergreen shrub or tree with a rounded crown, which can grow up to a height of 3-15 m. B. monandra is commonly known as a cow's foot, orchid tree, Napoleon plume, Flamboyant, and St Thomas tree (Starr and Starr, 2011). In the Yoruba tribe of South Western Nigeria, it is called "Abafe" (Ajiboye et al., 2015), and its decoction is taken to improve blood function, which is one of its health benefits. The tree is also fairly widely distributed throughout the natural grassland of Northern and South Eastern Nigeria (Agbugui et al., 2010). The leaf extract is bitter and traditionally used for the treatment of diabetes in Nigeria, Brazil (McCune and Johns, 2002), and Asia (Macedo, 2008). Its antidiabetic activity has been linked to the presence of antioxidant compounds (McCune and Johns, 2002), which have been studied (Argolo et al., 2004). Traditionally, the leaf extract has been used for treating postnatal bleeding (Onyije et al., 2012) and as the antidote for stonefish stings (Hansworth, 1990). Leaf decoction of $B$. monandra is one of the active ingredients of a blood tonic preparation in Nigeria. Moreover, the methanolic extract of B. monandra leaves (MEBmL) has been reported to possess hypoglycemic (Pepato et al., 2002), antioxidant (Argolo et al., 2004; Aderogba et al., 2006), antimicrobial (Ajiboye et al., 2015), anti-inflammatory (Campos et al. 2016; Solomon et al., 2016), and antinociceptive (Campos et al., 2016) activities. Hemagglutinating, trypsin inhibiting, and low disaccharide activities of the seed extracts have been reported (Abreu et al., 1990). In addition, several Bauhinia species are utilized as folk medicines worldwide, and studies have reported antimalarial, antiviral, antibacterial, antifungal, antidiarrheal, and antispasmodic activities (Onyije et al., 2012). Studies on the chemical composition of the leaves have led to the isolation of a wide range of bioactive compounds including quercetin-3-O-rutinoside and quercetin and $\beta$-carotene (Aderogba et al., 2006). Early phytochemical studies indicated that the species of this genus are rich sources of lactones, flavonoids, terpenoids, glycolipids, steroids, steroids, and tannins (Albuquerque and Silva, 2000; Da Silva et al., 2000; Mendes et al., 2006).

The folkloric claims made by tribal communities and abundant phytochemical contents inspired the present study. However, not many reports on the anti-thrombocytopenic activity of $B$. monandra are available in the literature. Therefore, the purpose of the present study was to determine the effect of the MEBmL as a potential antidote for thrombocytopenic disorder. 


\section{Materials and methods}

\section{Chemicals and experimental drug}

Heparin was purchased from Vangel Pharmaceuticals (Enugu, Nigeria). Methanol, acetic acid, lead acetate, sodium hydroxide, ethyl acetate, hydrochloric acid, tetraoxosulfate (VI) acid, chloroform, ethanol, and ferric chloride were obtained from the chemical store of the Department of Pharmacology and Toxicology, University of Nigeria, Nsukka, Nigeria. Solvents were redistilled before use while reagents were used without further purification. All chemicals and reagents were of analytical reagent grade.

\section{Collection of plant materials}

The aerial parts of $B$. monandra were collected from the Botanical Garden, University of Nigeria, Nsukka, Nigeria. The plant parts were taken to the Department of Plant Science and Biotechnology, University of Nigeria, Nsukka, Nigeria, where they were appropriately identified and authenticated with specimen voucher number, UNH 1559.

\section{Preparation of plant extract}

Fresh aerial leaves of $B$. monandra were washed with running tap water to remove dust and dirt. The leaves were then air-dried under shade for a period of 3 weeks and pulverized into powder and stored in plastic airtight containers for further processing. The pulverized leaves $(200 \mathrm{~g})$ were macerated in 11 of methanol and shaken properly. The mixture was allowed to stand for $72 \mathrm{hrs,}$ after which it was filtered using Whatman filter paper. The filtrate obtained was concentrated in a rotary evaporator and the resultant extract was preserved in airtight glass containers and stored at $4{ }^{\circ} \mathrm{C}$ in a refrigerator for subsequent use.

\section{Experimental animals}

Albino mice of both sexes, weighing between 25 and $32 \mathrm{~g}$, were obtained from the animal house of the Department of Pharmacology and Toxicology, University of $\mathrm{Ni}$ geria, Nsukka, Nigeria, and housed at $25^{\circ} \mathrm{C} \pm 5^{\circ} \mathrm{C}$ in a well-ventilated animal house under $12: 12 \mathrm{~h}$ light: dark cycle. The animals were maintained under standard conditions in the animal house of the Department of Pharmacology and Toxicology, University of Nigeria, Nsukka, Nigeria. All the animals were provided with a normal pellet diet and water ad libitum, and allowed to acclima- tize to environmental conditions prior to commencement of the experiment. The experimental protocol was approved by the Institutional Animal Ethics Committee of the University of Nigeria, Nsukka, Nigeria.

\section{Laboratory animal ethics}

The protocols governing the use and handling of laboratory animals were strictly followed as approved by the Animal Handling Ethics Committee, of University of Nigeria, Nsukka, Nigeria. These principles are also in accordance with the National Research Council Guide for Care and Use of Laboratory Animals (Gannon and Sikes, 2007).

\section{Preliminary phytochemical screening of $M E B m L$}

Phytochemical analyses of reducing sugars, proteins, carbohydrates, flavonoids, saponins, resins, steroids, oils, terpenoids, alkaloids, tannins, cardiac glycosides, and acidic compounds were carried out on the MEBmL using standard procedures (Vaghasiya et al., 2011; Ramamurthy and Sathiyadevi, 2017).

\section{Acute toxicity study}

The acute toxicity study of MEBmL was evaluated in mice according to the procedures outlined by the Organization for Economic Co-operation and Development (OECD, 2001). Following the fasting period, a single dose of $5000 \mathrm{mg} / \mathrm{kg}$ of crude extract was administered orally to three male and three female mice in the treatment groups. Remaining three male and three female mice were administered distilled water and were regarded as control groups. Food was allotted to the mice exactly $1 \mathrm{~h}$ after treatment. The mice were closely and carefully observed within the first 6 hrs for any indication of toxicity effect, daily for a duration of 14 days. The animals were visually observed daily for mortality, behavioral pattern, changes in physical appearance, injury, pain, and signs of illness during the duration of the study.

\section{Induction of thrombocytopenia}

Heparin was used to induce thrombocytopenia in the experimental animals. This was achieved by a subcutaneous injection of heparin at the dose of $2500 \mathrm{IU} / \mathrm{kg}$ body weight (b. wt) for 2 consecutive days.

\section{Experimental protocol of mice treated with the MEBmL}

A total of 30 albino mice were used for the experimental study. The animals were divided into five groups. Group I served as a normal control and received only 
distilled water for the duration of the study. Group II served as a positive control and was injected with heparin (2500 IU/kg b. wt, SC) daily for 2 days. Groups III, $\mathrm{IV}$, and $\mathrm{V}$ (treatment groups) were injected with heparin (2500 IU/kg b. wt, SC) daily for 2 consecutive days and afterwards received MEBmL (100, 200, and $400 \mathrm{mg} / \mathrm{kg}$ b. wt, PO, respectively) for 5 consecutive days. Blood samples were collected on day 0 , day 3 , day 6 , and day 8 from mice in all groups for blood platelet count evaluation.

\section{Examination of the platelet count in mice}

On day 0 , day 3 , day 6 , and day 8 of the experiment, blood samples were collected from the veins of mice with a $1 \mathrm{ml}$ syringe and put into heparinized specimen vials. The platelet count was determined using hemocytometer. The mean platelet counts $\left(\times 10^{3} / \mathrm{mm}^{3}\right)$ of mice in the five experimental groups were determined.

\section{Evaluation of the bleeding time in mice}

The bleeding time in the mice tested was determined by Duke's method (Lewis et al., 2002) with slight modifications. The tail of each mouse was carefully cut with scissors $1 \mathrm{~mm}$ from the end, and the time when bleeding started was noted down. The blood oozing from the tail was mopped with a filter paper at intervals of $30 \mathrm{~s}$, until the bleeding stopped. The time between the beginning and the end of bleeding was noted down as the bleeding time.

\section{Evaluation of the blood clotting time in mice}

The blood clotting time in the mice tested was estimated by the capillary glass tube method (Provan and Krentz, 2002). Blood samples were collected via the retroorbital venous sinus with a glass capillary tube. The capillary tube was broken at one end every $30 \mathrm{~s}$ until a fibrin thread was formed. The total time taken for the fibrin thread to form was noted down as the clotting time.

\section{Statistical analysis}

The recorded values were expressed as mean $( \pm$ SEM) and subjected to an independent t-test analysis. The values of $P<0.05$ were considered significant.

\section{Results}

\section{Preliminary phytochemical screening of $M E B m L$}

The rough phytochemical analysis of $B$. monandra extracts revealed the presence of important medicinal constituents. The medicinal phytochemicals found were as follows: reducing sugars, proteins, carbohydrates, flavonoids, saponins, resins, steroids, oils, terpenoids, alkaloids, tannins, and cardiac glycosides. The results of the preliminary phytochemical screening showed that the MEBmL is rich in proteins, saponin, oils, alkaloids, and tannins (Table 1).

Table 1. Preliminary phytochemical analysis of methanolic extract of Bauhinia monandra leaves

\begin{tabular}{l|c}
\hline \multicolumn{1}{c|}{ Plant constituents } & Inference \\
\hline Reducing sugar & + \\
\hline Proteins & +++ \\
\hline Carbohydrate & + \\
\hline Flavonoid & ++ \\
\hline Saponin & ++ \\
\hline Acidic compounds & + \\
\hline Resin & ++ \\
\hline Steroids & ++ \\
\hline Oils & + \\
\hline Terpenoid & ++ \\
\hline Alkaloid & +++ \\
\hline Tannins & + \\
\hline Cardiac glycosides & + present; ++ moderately present; \\
\hline++- highly present; - & absent \\
\hline
\end{tabular}

\section{Acute toxicity $\left(L D_{50}\right)$ of the $M E B m L$}

In acute toxicity, no early or late (when observed for 14 days) mortality was observed in mice administered with single doses of the leaf methanolic extract at $5000 \mathrm{mg} / \mathrm{kg}$ b. wt. No animal showed any significant alteration in behavioral, physiological, and physical activities. The indication is that the oral administration of $B$. monandra extract did not produce any visible toxic effects.

\section{Effect of HIT on the physical activity of mice}

After the induction of thrombocytopenia, weakness and no aggressive behavior/lack of aggression were observed in animals when they were handled or pricked with the needle. General toxic signs that were observed following the subcutaneous injection of heparin included depression, suppressed movement, anorexia, emacia- 
Table 2. Effect of methanolic extract of Bauhinia monandra leaves on mean platelet counts in tested mice

\begin{tabular}{|c|c|c|c|c|c|}
\hline \multirow{2}{*}{\multicolumn{2}{|c|}{ Groups }} & \multicolumn{4}{|c|}{ Mean platelet counts $\left[10^{3} / \mathrm{mm}^{3}\right]$} \\
\hline & & \multirow{2}{*}{$\begin{array}{c}\text { day } 0 \\
\text { (baseline) } \\
172.25 \pm 7.93\end{array}$} & \multirow{2}{*}{$\begin{array}{c}\text { day } 3 \\
\text { (after induction) } \\
180.46 \pm 9.75\end{array}$} & \multirow{2}{*}{$\begin{array}{c}\text { day } 6 \\
\text { (3 days post treatment) } \\
188.35 \pm 5.95 \\
(4.37)\end{array}$} & \multirow{2}{*}{$\begin{array}{c}\text { day } 8 \\
\text { (5 days post treatment) } \\
181.90 \pm 11.38 \\
(0.80)\end{array}$} \\
\hline G I & $\begin{array}{l}\text { normal control } \\
\text { (vehicle only) }\end{array}$ & & & & \\
\hline G II & $\begin{array}{l}\text { positive control } \\
\text { (vehicle }+ \text { inducer) }\end{array}$ & $190.30 \pm 4.60$ & $94.90 \pm 3.77^{* * *}$ & $\begin{array}{c}104.95 \pm 3.67^{* * * \mathrm{a}} \\
(10.59)\end{array}$ & $\begin{array}{c}127.65 \pm 5.79 * * \\
(34.51)\end{array}$ \\
\hline G III & $\begin{array}{l}\text { B. monandra extract } \\
((100 \mathrm{mg} / \mathrm{kg}, \mathrm{b} . \mathrm{wt})+\text { inducer })\end{array}$ & $197.10 \pm 1.87$ & $93.70 \pm 1.48^{* * *}$ & $\begin{array}{l}180.15 \pm 0.88^{\mathrm{a}} \\
\quad(92.26)\end{array}$ & $\begin{array}{l}200.50 \pm 13.58^{b} \\
(113.98)\end{array}$ \\
\hline G IV & $\begin{array}{l}\text { B. monandra extract } \\
((200 \mathrm{mg} / \mathrm{kg}, \mathrm{b} . \mathrm{wt})+\text { inducer })\end{array}$ & $178.80 \pm 9.47$ & $93.15 \pm 6.59^{* * *}$ & $\begin{array}{l}173.70 \pm 2.01^{* \mathrm{a}} \\
\quad(86.47)\end{array}$ & $\begin{array}{l}186.55 \pm 5.13^{\mathrm{a}} \\
\quad(100.27)\end{array}$ \\
\hline G V & $\begin{array}{l}\text { B. monandra extract } \\
((400 \mathrm{mg} / \mathrm{kg}, \mathrm{b} . \mathrm{wt})+\text { inducer })\end{array}$ & $192.75 \pm 5.52$ & $98.75 \pm 1.92^{* * *}$ & $\begin{array}{l}192.60 \pm 2.42^{\mathrm{a}} \\
\quad(95.04)\end{array}$ & $\begin{array}{c}225.10 \pm 6.41^{* a} \\
(127.95)\end{array}$ \\
\hline
\end{tabular}

All values are represented as mean $\pm \mathrm{SEM} ; \mathrm{n}=5 ;{ }^{* *} P<0.001 ;{ }^{* *} P<0.01 ;{ }^{*} P<0.05$, when all groups compared normal control group; ${ }^{\mathrm{a}} P<0.001 ;{ }^{\mathrm{b}} P<0.01 ;{ }^{\mathrm{c}} P<0.05$, when all groups compared to positive control group; all values in parenthesis are percentage increase of platelet count calculated relative to day 3 of groups

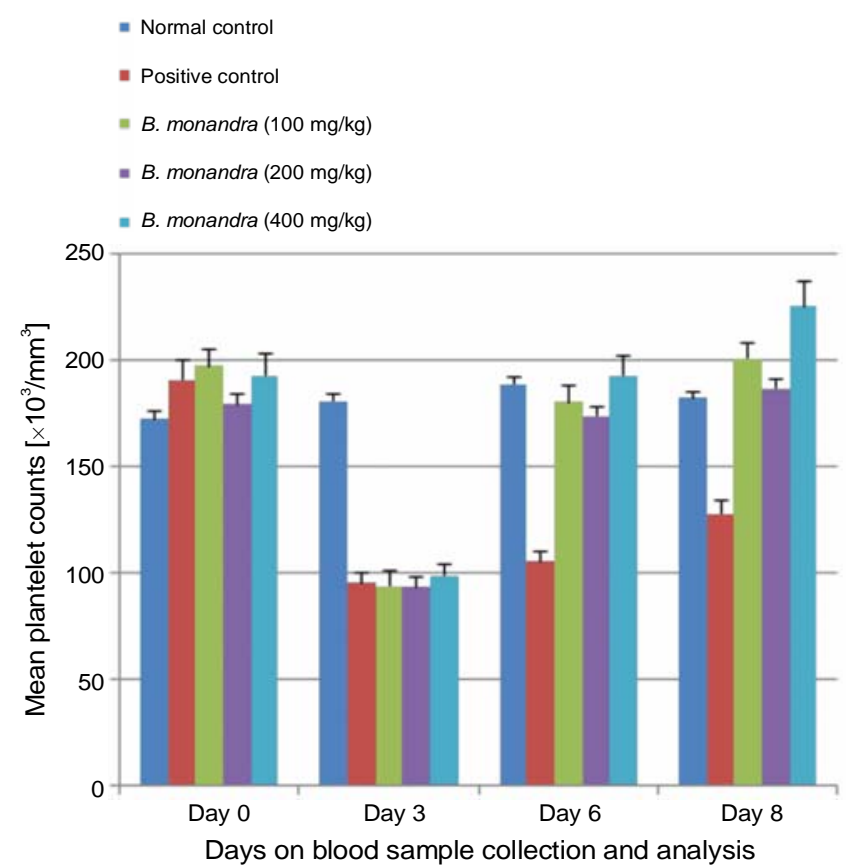

Fig. 1. Effect of methanolic extract of Bauhinia monandra leaves on mean platelet counts

tion, stupor, and/or coma. This may indicate a deteriorating health condition of animals due to thrombocytopenia. However, these physical conditions improved when treatment with the MEBmL was complete.

\section{Effect of $\mathrm{MEBmL}$ on the platelet count in tested mice}

An injection of $2500 \mathrm{IU} / \mathrm{kg}$ (subcutaneous) heparin for 2 consecutive days reduced the platelet count in

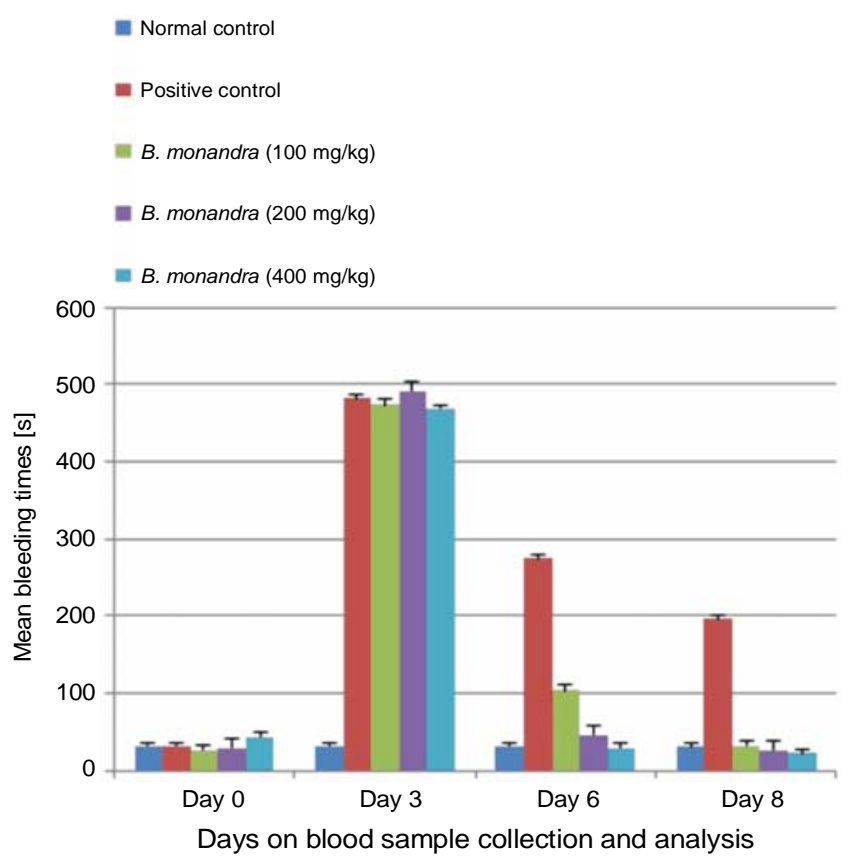

Fig. 2. Effect of methanolic extract of Bauhinia monandra leaves on mean bleeding times

mice, followed by its increase over the subsequent days (Table 2). There was no statistical difference in the baseline mean platelet count among all groups. The change in the mean platelet counts of the mice in all tested groups indicates a similar trend: a reduction in the platelet count after heparin administration and a significant $(P<0.05)$ increase over the subsequent days after treatment with MEBmL as was observed in Groups III-V, 
Table 3. Effect of methanolic extract of Bauhinia monandra leaves on mean bleeding times in tested mice

\begin{tabular}{|c|c|c|c|c|c|}
\hline \multirow{2}{*}{\multicolumn{2}{|c|}{ Groups }} & \multicolumn{4}{|c|}{ Mean bleeding times [s] } \\
\hline & & day 0 & day 3 & day 6 & day 8 \\
\hline G I & $\begin{array}{l}\text { normal control } \\
\text { (only vehicle) }\end{array}$ & $31.25 \pm 2.75$ & $31.21 \pm 2.44$ & $31.98 \pm 2.85$ & $30.83 \pm 2.35$ \\
\hline G II & $\begin{array}{l}\text { positive control } \\
\text { (vehicle }+ \text { inducer) }\end{array}$ & $31.59 \pm 2.01$ & $481.60 \pm 3.80^{* * *}$ & $\begin{array}{l}274.97 \pm 2.27 * * * \\
(42.91)\end{array}$ & $\begin{array}{c}196.30 \pm 2.37^{* * * a} \\
(59.24)\end{array}$ \\
\hline G III & $\begin{array}{l}\text { B. monandra extract } \\
((100 \mathrm{mg} / \mathrm{kg}, \mathrm{b} . \mathrm{wt})+\text { inducer })\end{array}$ & $26.07 \pm 2.50$ & $473.93 \pm 13.31^{* * *}$ & $\begin{array}{l}103.31 \pm 3.83^{* * * \mathrm{a}} \\
(78.20)\end{array}$ & $\begin{array}{l}31.34 \pm 1.53^{\mathrm{a}} \\
\quad(93.39)\end{array}$ \\
\hline G IV & $\begin{array}{l}\text { B. monandra extract } \\
((200 \mathrm{mg} / \mathrm{kg}, \mathrm{b} . \mathrm{wt})+\text { inducer })\end{array}$ & $28.48 \pm 6.41$ & $491.03 \pm 4.00^{* * *}$ & $\begin{array}{l}45.24 \pm 4.44^{* \mathrm{a}} \\
\quad(90.79)\end{array}$ & $\begin{array}{l}26.06 \pm 1.89^{\mathrm{a}} \\
\quad(94.69)\end{array}$ \\
\hline G V & $\begin{array}{l}\text { B. monandra extract } \\
((400 \mathrm{mg} / \mathrm{kg}, \mathrm{b} . \mathrm{wt})+\text { inducer })\end{array}$ & $42.83 \pm 13.38$ & $469.13 \pm 19.16^{* * *}$ & $\begin{array}{l}29.51 \pm 1.57^{\mathrm{a}} \\
\quad(93.71)\end{array}$ & $\begin{array}{l}21.41 \pm 1.66^{* \mathrm{a}} \\
\quad(95.44)\end{array}$ \\
\hline
\end{tabular}

All values are represented as mean $\pm \mathrm{SEM} ; n=5 ;{ }^{* *} P<0.001 ;{ }^{* *} P<0.01 ;{ }^{*} P<0.05$, when all groups compared normal control group; ${ }^{\mathrm{a}} P<0.001 ;{ }^{\mathrm{b}} P<0.01 ;{ }^{\mathrm{c}} P<0.05$, when all groups compared to positive control group; all values in parenthesis are percentage reduction of bleeding times calculated relative to day 3 of groups

compared to control groups (Fig. 1). The administration of MEBmL at different concentrations $(100,200$, and $400 \mathrm{mg} / \mathrm{kg})$ showed a significant increase $(92.26,86.47$, and $95.04 \%$, respectively) in the mean platelet count after 3 days, compared to the normal control group (4.37\%) treated with distilled water only (Table 2). The positive control group showed $10.59 \%$ increase in mean platelet counts after 3 days of treatment with distilled water. Treatment with MEBmL (100, 200, and $400 \mathrm{mg} / \mathrm{kg})$ also showed a significant $(P<0.05)$ increase in mean platelet counts $(113.98,100.27$, and $225.10 \%$, respectively) after 5 days in a dose-dependent manner, compared to the normal control $(0.80 \%)$ and positive control (34.51\%) groups (Table 2).

\section{Effect of MEBmL on the bleeding time in tested mice}

The trend in the influence of the $B$. monandra extract on the bleeding time was similar for all mice; the mean bleeding times significantly increased after heparin administration and decreased after a concurrent treatment with MEBmL for animals from Groups III-V (Fig. 2). There was no significant difference in the initial mean bleeding times in mice from all groups. The mean bleeding times in mice increased after administration of heparin to animals in all groups and reduced significantly after 3 and 5 days treatment with MEBmL to mice from Groups III-V. Administration of MEBmL at different concentrations $(100,200$ and $400 \mathrm{mg} / \mathrm{kg})$ showed a significant $(P<0.05)$ reduction in the mean bleeding times after the $3^{\text {rd }}(78.20,90.79$ and 93.71 respectively $)$ and $5^{\text {th }}$
(59.24, 93.39 and $95.44 \%$ respectively) day of treatment, compared to the positive control (59.24\%) group, in a dose-related manner (Table 3 ).

\section{Effect of MEBmL on the blood clotting time in tested mice}

The effect of $B$. monandra on the blood clotting time in mice also presented a similar trend. A significant $(P<0.05)$ increase in the blood clotting time after the administration of heparin and a simultaneous reduction after a concurrent treatment of mice with $\mathrm{MEBmL}$ were observed (Fig. 3). There was no statistical significance in the difference between the initial mean blood clotting times in mice in all tested groups. After 3 days of treatment with MEBmL $(100,200$, and $400 \mathrm{mg} / \mathrm{kg})$, a reduction in mean clotting times $(43.40,72.41$, and $78.47 \%$, respectively) was observed in mice, compared to the positive control (9.02\%) group (Table 4). After 5 days, a significant reduction in mean clotting times (64.38, 76.13 , and $78.92 \%$ ) was observed in mice treated with $\operatorname{MEBmL}(100,200$, and $400 \mathrm{mg} / \mathrm{kg}$, respectively), compared to the positive control group (40.16\%).

\section{Discussion}

Researches on herbal medicinal products for platelet augmentation are rapidly increasing in numbers due to limited supportive treatments available for thrombocytopenic disorders (Arollado et al., 2013). On the basis of the traditional use of $B$. monandra leaves for blood function improvement, and in the absence of a report vali- 


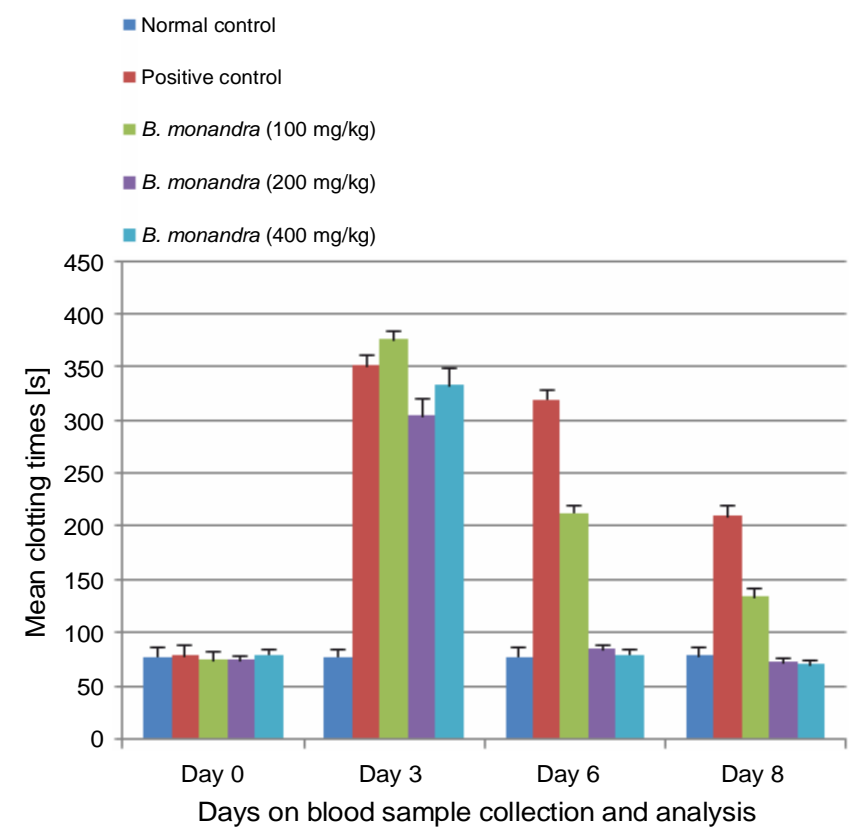

Fig. 3. Effect of methanolic extract of Bauhinia monandra leaves on mean clotting times

dating this claim, we evaluated its platelet augmentation activity in HIT through well-established experimental methods. First, MEBmL was subjected to phytochemical screening and the results showed the presence of alkaloids, tannins, flavonoids, terpenoids, saponin, glycosides, and steroids. The methanolic extract of $B$. monandra was evaluated for acute toxicity in mice, and no significant physical and behavioral changes were observed at higher concentrations of $5000 \mathrm{mg} / \mathrm{kg} \mathrm{b}$. wt, and no mortality was observed after 14 days of administration of the extract. This result indicates that an oral intake of the leaf extract of $B$. monandra may be deemed safe.

Thrombocytopenia is a pathological condition, often characterized by an abnormally low blood platelet count, which results in an impaired process of stopping bleeding by clumping and clotting blood vessel injuries (Balduini and Melazzini, 2017). In the present study, heparin was used as an agent for an experimental induction of thrombocytopenia. This method was also validated and used in other studies worldwide (Bhavya et al., 2015; Roihatul et al., 2016). In HIT, the immune system produces antibodies (IgG class) against heparin, which bind to platelet factor-4 (PF4). This 70-amino acid long protein neutralizes heparin-like molecules on the endothelial surface of blood vessels, thereby inhibiting local antithrombin III and promoting coagulation (Warkentin, 2006; Ahmed et al., 2007; Visentin and Liu,
2007; Warkentin et al., 2008). The IgG antibodies form a complex with heparin and PF4 in the blood, resulting in platelet activation and formation of platelet microparticles that rapidly initiate the formation of blood clots; as a consequence a reduction in the platelet count leads to thrombocytopenia.

In the present study, a heparin injection induced thrombocytopenia in mice and caused a significant $(P<0.05)$ reduction in blood platelet counts (Fig. 1$)$. It also resulted in a significant $(P<0.05)$ increase in the bleeding time (Fig. 2) and the clotting time (Fig. 3) of mice, as compared to the control group. Since the recovery from HIT usually begins within 1-3 days after stopping the drug intake and typically completes within 7-10 days (George et al., 1998; Aster et al., 2009; George and Aster, 2009), the analysis of blood samples was done 3 and 5 days post-treatment. As observed in the present study, treating mice with different concentrations of the MEBmL (100, 200, and $400 \mathrm{mg} / \mathrm{kg})$ showed a significant $(P<0.05)$ increase in mean platelet counts (Table 2 ), and also showed a significant $(P<0.05)$ reduction in the mean bleeding times (Table 3 ) and the mean blood clotting times (Table 4) of mice in both groups during the 5-day treatment. Among the different concentrations of $B$. monandra administered, $400 \mathrm{mg} / \mathrm{kg}$ b. wt showed the highest potential, followed by $100 \mathrm{mg} / \mathrm{kg} \mathrm{b}$. wt and $200 \mathrm{mg} / \mathrm{kg} \mathrm{b}$. wt. This result indicates that the potential of the $B$. monandra extract for improving the health condition in HIT is not dose-related (Fig. 1); however, its activity in reducing the bleeding and clotting times is dose-related (Fig. 2 and Fig. 3). It is noticeable that the extract exhibited complete restoration of the platelet count back to the normal levels within 3 days of thrombocytopenic induction (Table 2). Therefore, it is worth noting that since there is no current antidote for heparin overdose or poisoning, the leaf extract of $B$. monandra provides the logical basis for consideration as a potential antidote for HIT.

The likely mode of action of the extract may include inhibiting the activity of antithrombin III or stopping the inhibition of the clotting factor X and IXa (Di Micco et al. 2000 ) or even the inhibition of IgG antibodies. However, since thrombocytopenia was established in experimental animals before the treatments began, and considering the significant effect presented by the extract to substantially increase the platelet count (Fig. 1), we can assume that this extract has a stimulatory action on the 
Table 4. Effect of methanolic extract of Bauhinia monandra leaves on mean clotting times in tested mice

\begin{tabular}{|c|c|c|c|c|c|}
\hline \multirow{2}{*}{\multicolumn{2}{|c|}{ Groups }} & \multicolumn{4}{|c|}{ Mean clotting times [s] } \\
\hline & & \multirow{2}{*}{$\begin{array}{c}\text { day } 0 \\
77.57 \pm 7.56\end{array}$} & \multirow{2}{*}{$\begin{array}{c}\text { day } 3 \\
77.32 \pm 6.94\end{array}$} & \multirow{2}{*}{$\begin{array}{c}\text { day } 6 \\
77.35 \pm 6.23\end{array}$} & \multirow{2}{*}{$\begin{array}{c}\text { day } 8 \\
77.84 \pm 8.27\end{array}$} \\
\hline G I & $\begin{array}{l}\text { positive control } \\
\text { (vehicle + inducer) }\end{array}$ & & & & \\
\hline G II & $\begin{array}{l}\text { positive control } \\
\text { (vehicle + inducer) }\end{array}$ & $78.04 \pm 7.98$ & $350.99 \pm 14.38^{* * *}$ & $\begin{array}{c}319.34 \pm 9.92^{* * *} \\
(9.02)\end{array}$ & $\begin{array}{c}210.02 \pm 16.43^{* * *} \\
(40.16)\end{array}$ \\
\hline G III & $\begin{array}{l}\text { B. monandra extract } \\
((100 \mathrm{mg} / \mathrm{kg}, \mathrm{b} . \mathrm{wt})+\text { inducer })\end{array}$ & $73.98 \pm 3.80$ & $375.89 \pm 7.01^{* * *}$ & $\begin{array}{c}212.75 \pm 3.95^{* * * \mathrm{a}} \\
(43.40)\end{array}$ & $\begin{array}{c}133.88 \pm 4.73^{* * * b} \\
(64.38)\end{array}$ \\
\hline G IV & $\begin{array}{l}\text { B. monandra extract } \\
((200 \mathrm{mg} / \mathrm{kg}, \mathrm{b} . \mathrm{wt})+\text { inducer })\end{array}$ & $73.78 \pm 2.89$ & $304.22 \pm 6.48^{* * *}$ & $\begin{array}{l}83.94 \pm 4.29^{\mathrm{a}} \\
\quad(72.41)\end{array}$ & $\begin{array}{l}72.62 \pm 2.30^{\mathrm{a}} \\
\quad(76.13)\end{array}$ \\
\hline G V & $\begin{array}{l}\text { B. monandra extract } \\
((400 \mathrm{mg} / \mathrm{kg}, \mathrm{b} . \mathrm{wt})+\text { inducer })\end{array}$ & $79.20 \pm 8.66$ & $332.63 \pm 19.97^{* * *}$ & $\begin{array}{l}79.45 \pm 10.51^{\mathrm{a}} \\
\quad(78.47)\end{array}$ & $\begin{array}{l}70.13 \pm 6.71^{\mathrm{a}} \\
\quad(78.92)\end{array}$ \\
\hline
\end{tabular}

All values are represented as mean $\pm \mathrm{SEM} ; n=5 ;{ }^{* *} P<0.001 ;{ }^{* *} P<0.01 ;{ }^{*} P<0.05$, when all groups compared normal control group; ${ }^{\mathrm{a}} P<0.001 ;{ }^{\mathrm{b}} P<0.01 ;{ }^{\mathrm{c}} P<0.05$, when all groups compared to positive control group; all values in parenthesis are percentage reduction of bleeding times calculated relative to day 3 of groups

activation of megakaryocytes, leading to an increased platelet production (Muhury et al., 2009). However, the actual mode of action is yet to be determined. In order to elucidate the possible mode of action of the antithrombocytopenic activity of the extract of $B$. monandra, we performed a complete investigation of literature, which revealed the presence of two galactose-specific lecithins, whichare carbohydrate-binding proteins macromolecules that are highly specific for sugar moieties of other molecules (Coelho and Silva, 2000; Souza et al., 2011). The first was purified from the leaves of $B$. monandra (Coelho and Silva, 2000), and the other one was purified from $B$. monandra roots and showed termiticidal activity on Nasutitermes corniger and antifungal activity on pathogenic Fusarium species (Souza et al., 2011). Research has also shown that lecithin possesses a wide range of properties such as antifungal (Costa et al., 2010), antibacterial (Oliveira et al. 2008; Costa et al., 2010), antiproliferative (Aranda-Souza et al., 2014), antidiabetic (Rocha et al., 2013), antiplatelet aggregation (Granguly and Fossett, 1981), or analgesic (Leite et al., 2012).

Preliminary phytochemical studies of MEBmL revealed the presence of alkaloids, tannins, flavonoids, terpenoids, saponin, glycosides, steroids, and acidic compounds (Table 1). Although based on the results of the study we were unable to associate any of these constituents with the activity observed, some of the bioactive phytoconstituents have been reported in previous studies to evoke various influence on hematopoiesis. For instance, two ellagic acid compounds have been reported to improve platelet production by inducing megakaryocyte differentiation in human erythroleukemia cells (Goa et al., 2014). Plant tannins have also been reported by Xiong et al. (2014) to significantly increase red blood cell, white blood cell, and platelet counts in mice with myelosuppression. Chen et al. (2017) reported that plant saponins and their component glycosides possess hematopoietic activities in in vitro and in vivo mouse models, which involve promoting focal adhesion kinase and extracellular signal-regulated kinase $1 / 2$ activation and modulating cytokine production in the bone marrow. Similarly, Zhang et al. (2017) reported that a combination of four isolated plant flavonoids possesses a potent hematopoietic activity by a possible activation of a regulator of erythropoietin transcription. Another study by Sun et al. (2012) also revealed that terpene glycosides possess hemostatic properties.

Several studies have been conducted on the pharmacological activities of $B$. monandra extracts (Argolo et al., 2004; Macedo, 2008; Agbugui et al., 2010; Starr and Starr, 2011; Ajiboye et al., 2015), but no study was conducted on the effect of the $B$. monandra extract on platelet augmentation or to analyze its hematopoietic potential. However, a previous report revealed that a high content of iron in the extract may assist blood formation (Agbugui et al., 2010). Moreover, previous studies have also reported the use of other plants in platelet augmentation (Osime et al., 2008; Arollado and Osi, 2010; Apostol et al., 2012; Arollado et al., 2013). In this 
context, the extracts from Carica papaya, Ipomea batatas, and Euphorbia hirta leaves promoted an increase in platelet counts initially in rats, which was reduced by oral administration of anagrelide (synthetic quinazoline derivative that reduces platelet production) (Arlollado et al., 2013). Further research is also needed to isolate and characterize the compounds responsible for the platelet augmentation activity to further elucidate the most possible mode of action.

\section{Conclusions}

B. monandra is a very promising medicinal plant used in folk medicine for treating, curing, and managing many ailments. The methanolic extract of $B$. monandra leaves showed rapid and promising results in the management of HIT. This result provided experimental evidence for the effective use of $B$. monandra in traditional medicine to improve blood function. Based on the evidence from this study, we can conclude that the MEBmL can be used as an antidote in the management of thrombocytopenia disorders.

\section{References}

Abreu M., Castillo A., Rodriguez N., Pinon D. (1990) Effect of the ingestion of an extract from Bauhinia monandra seeds on rats. Nahrung 34: 689-693.

Aderogba M.A., Ogundaini A.O., Eloff J.N. (2006) Isolation of two flavonoids from Bauhinia monandra (Kurz) leaves and their antioxidant effects. Afr. J. Trad. Compl. Alter. Med. 3: 59-63.

Agbugui M., Oniye S.J., Auta J. (2010) Effects of processing on the mineral content, proximate composition and phytochemical factors of the seeds of Bauhinia monandra (Kurz). Bajopas 3: 23-25.

Ahmed I., Majeed A., Powell R. (2007) Heparin induced thrombocytopenia: diagnosis and management update. Postgrad. Med. J. 83: 575-582.

Ajiboye A.T., Musa M.D., Otun K.O., Jimoh A.A., Bale A.T., Lawal S.O., Arowona M.T. (2015) The studies of antioxidant and antimicrobial potentials of the leaf extract of Bauhinia monandra plant. Nat. Prod. Chem. Res. 3: 180.

Albuquerque A.B.P., Silva A.V. (2000) Pharmacobotanical study of species in the treatment of diabetes. Acta. Pharm. Bonaer. 19: 7-12.

Apostol J., Gan J.V.A., Raynes R.J.B., Sabado A.A.S., Carigma A.Q., Santiago L.A., Ysrael M.C. (2012) Platelet-increasing effects of Euphorbia hirta Linn. (Euphorbiaceae) in ethanol-induced thrombocytopenic rat models. Int. J. Pharm. Front. Res. 2: 1-11.

Aranda-Souza M.A., Rossato F.A., Costa R.A.P., Figueira T.T., Castilho R.F., Guarniere M.C., Nunes E.S., Coelho
L.C.B.B., Correia M.T.S., Vercesi A.E. (2014) A lectin from Bothropsleucurus snake venom raises cytosolic calcium levels and promotes B16-F10 melanoma necrotic cell death via mitochondrial permeability transition. Toxicon 82: 97-103.

Argolo A.C.C., Sant'Ana A.E.G., Pletsch M., Coelho L.C.B.B. (2004) Antioxidant activity of leaf extracts from Bauhinia monadra. Bioresour. Technol. 95: 229-233.

Arollado E.C., Osi M.O. (2010) Hematinic activity of Alternanthera sessilis (L.) R.Br. (Amaranthaceae) in mice and rats. E-Intern. Sci. Res. J. 2.

Arollado E.C., Peňa I.G., Dahilig V.R.A. (2013) Platelet augmentation activity of selected Philippine plants. Int. J. Pharm. Phytopharmacol. Res. 3: 121-123.

Aster R.H., Bougie D.W. (2007) Drug-induced immune thrombocytopenia. N. Eng. J. Med. 357: 580-587.

Aster R.H., Curtis B.R., McFarland J.G., Bougie D.W. (2009) Drug-induced immune thrombocytopenia: pathogenesis, diagnosis and management. J. Thromb. Haemost. 7: 911-918.

Balduini C.L., Melazzini F. (2017) Research at the heart of hematology: thrombocytopenias and platelet function disorders. Haematologica 102: 203-205.

Bhavya R., Jyothi Y., Syed I.R. (2015) Potential benefits of Boerhaviadiffusa leaves extract for the management of thrombocytopenia in Sprague Dawley rats. RJPBCS 6: 925-928.

Campos J.K.L., Araújo C.S.F., Arau 'jo T.F.S., Santos A.F.S., Teixeira J.A., Lima V.L.M., Coelho L.C.B.B. (2016) Antiinflammatory and antinociceptive activities of Bauhinia monandra leaf lectin. Biochimie Open 2: 62-68.

Chen X., Li B., Goa Y., Ji J., Wu Z., Chen S. (2017) Saponin from Sanguisorba officinalis improve hematopoiesis by promoting survival through FAK and Erk1/2 activation and modulating cytokine production in bone marrow. Front Pharmacol. 8: 130.

Coelho L.C.B.B., Silva M.B.R. (2000) Simple method to purify milligram quantities of the galactose-specific lectin from the leaves of Bauhinia monandra. Phytochem. Anal. 11: 295-300.

Costa R.M.P.B., Vaz A.F.M., Oliva M.L.V., Coelho L.C.B.B., Correia M.T.S., Carneiro-Da-Cunha M.G. (2010) A new mistletoe Phthirusa pyrifolia leaf lectin with antimicrobial properties. Process Biochem. 45: 526-533.

Da Silva K.L., Biavatti M.W., Leite S.N., Yunes R.A., Delle M.F., Cechinel F.V. (2000) Phytochemical and pharmacognostic investigation of Bauhinia forficate Link (Leguminosae). Z. Naturforsch C. 55: 478-480.

Di Micco B., Caen J., Colonna G., Macalello M.A., Marchese M., Stiuso P., Di Micco P., Morelli F., Metafora S. (2000) Inhibition of antithrombin by protein SV-IV normalizes the coagulation of hemophilic blood. Eur. J. Pharmacol. 391: 1-9.

Evans P., Halliwell B. (2001) Micronutrients: oxidants/antioxidants status. Br. J. Nutr. 85(Suppl. 2): S67-S74.

Gannon W.L., Sikes R.S. (2007) Guidelines of the American Society of Mammalogists for the use of wild mammals in research. J. Mammal. 88: 809-823. 
George J.N., Aster R.H. (2009) Drug-induced thrombocytopenia: pathogenesis, evaluation, and management. Hematology. Am. Soc. Hematol. Educ. Program 2009: 153-158.

George J.N., Raskob G.E., Shah S.R., Rizvi M.A., Hamilton S.A., Osborne S., Vondracek T. (1998) Drug-induced thrombocytopenia: a systematic review of published case reports. Ann. Intern. Med. 129: 886-890.

Goa X., Wu J., Zou W., Dai Y. (2014) Two ellagic acids isolated from roots of Sanguisorba officinalis L. promote hematopoietic progenitor cell proliferation and megakaryocyte differentiation. Molecules 19: 5448-5458.

Gowri S.S., Pavitha S., Vasantha K. (2011) Free radical scavenging capacity and antioxidant activity of young leaves and barks of Acacia nilotica (L.). Del. Int. J. Pharm. Pharmaceut. Sci. 3: 160-164.

Hansworth D.K. (1990) Traditional medicinal plants of Rarotonga, Cook Islands Part I. Int. J. Crude Drug Res. 28: 209-218.

Kamthe K., Kulkarni O. (2017) Evaluating effect of Cap PMA on platelet count in endemic fevers - a case series in Pune (Maharashtra, India). J. Pharm. Res. 11: 78-82.

Kantarjian H., Giles F., List A., Lyons R., Sekeres M.A., Pierce S., Deuson R., Leveque J. (2007) The incidence and impact of thrombocytopenia in myelodysplastic syndromes. Cancer 109: 1705-1714.

Keay R.W.J., Stanfield D.P., Onochie C.F.A. (1989) Trees of Nigeria. Clarendo Press Oxford.

Leite J.F.M., Assreuy A.M.S., Mota M.R.L., Bringel P.H.S.F., Lacerda R.R., Gomes V.M., Cajazeiras J.B., Nascimento K.S., Pessoa H.L.F., Gadelha C.A.A., Delatorre P et al. (2012) Antinociceptive and anti-inflammatory effects of a lectin like substance from Clitoria fairchildiana $R$. howard seeds. Molecules 17: 3277-3290.

Lewis S.M., Bain B.J., Bates I (Eds). (2002) Dacie and Lewis Practical Hematology (9th ed). London: Churchill Livingstone.

Macedo M.F.S. (2008) Determining the genotoxicity of an aqueous infusion of Bauhinia monandra leaves. Rev. Bras. Farmacogn. 18: 509-516.

McCune L.M., Johns T. (2002) Antioxidant activity in medicinal plants associated with the symptoms of diabetics mellitus used by the Indegenous people of the North American boreal forest. J. Ethnopharmacol. 82: 197-205.

Mendes B.G., Machado M.J., Falkenberg M. (2006) Triagem de glicolipidsemplantasmedicinais. Rev. Bras. Farmacogn. 16: 568-575.

Muhury M., Mathai A.M., Sharanda R., Naik R., Pai M.R., Sinha R. (2009) Megakaryocytic alterations in thrombocytopenia: a bone marrow aspiration study. Indian J. Pathol. Microbiol. 52: 490-494.

OECD (2001) OECD Guidelines for acute toxicity of chemicals. Paris: Organization for Economic Co-operation and Development.

Oliveira M.D.L., Andrade C.A.S., Santos-Magalhaes, Coelho L.C.B.B., Teixeira J.A.C., Carneiro-da-Cunha M.G., Correia M.T.S. (2008) Purification of a lectin from Eugenia uni- flora $L$. seeds and its potential antibacterial activity. Lett. Appl. Microbiol. 46: 371-376.

Onyije F.M., Avwioro O.G., Waritimi E.G. (2012) Evaluation of nephrotoxic effect of Bauhinia monandra on the kidney of alloxan induced diabetic rats. JPCS 4: 7-9.

Ortel T.L. (2009) Heparin-induced thrombocytopenia: when a low platelet count is a mandate for anticoagulation hematology. Am. Soc. Hematol. Educ. Program. 2009: 225-232.

Osime E.O., Ediale G.E., Omoti C.E., Famodu A.A. (2008) Effect of sweet potato leaf (Ipomoea Batatas) extract on some haematological parameters using rabbits. J. Med. Biomed. Res. 7: 12-15.

Pepato M.T., Keller E.H., Baviera A.M., Kettelhut I.C., Vendramini R.C., Brunetti I.L. (2002) Anti-diabetic activity of Bauhinia forficate decoction in streptozotocin-diabetic rats. J. Ethnopharmacol. 81: 191-197.

Peterson J.A., Nelson T.N., Kanack A.J., Aster R.H. (2008) Fine specificity of drug-dependent antibodies reactive with a restricted domain of platelet GP IIIa. Blood 111: 1234-1239.

Provan D., Krentz A. (2002) Oxford handbook of clinical and laboratory investigations. Oxford University Press Oxford.

Ramamurthy V., Sathiyadevi M. (2017) Preliminary phytochemical screening of methanol extract of Indigo feratrita Linn. J. Mol. Histol. Med. Physiol. 2: 122.

Rocha A.A., Araujo T.F.S., Fonseca C.S.M., Mota D.L., Medeiros P.L., Paiva P.M.G., Coelho L.C.B.B., Correia M.T.S., Lima V.L.M. (2013) Lectin from Crataevatapia bark improves tissue damages and plasma hyperglycemia in alloxan-induced diabetic mice. Evid. Based Compl. Altern. Med. 3.

Roihatul Z., Harjanto J.M., Junaidi K., Ita R., Riami. (2016) Mechanism of fruit ethanol extract of Phoenix dactylifera on heparin induced thrombocytopenia in rats. Der Pharmacia Lettre 8: 126-131.

Solomon S., Muruganantham N., Senthamilselvi M.M. (2016) Anti-oxidant and anti-inflammatory activity of Bauhinia Tomentosa (Flowers). Indo Am. J. Pharm. Res. 6: 4321-4326.

Souza J.D., Silva M.B.R., Argolo A.C.C., Napoleao T.H., Sa R.A., Correia M.T.S., Paiva P.M.G, Silva M.D.C., Coelho L.C.B.B. (2011) A new Bauhinia monandra galactose-specific lectin purified in milligram quantities from secondary roots with antifungal and termiticidal activities. Int. Biodeterior. Biodegrad. 65: 696-702.

Starr F., Starr Kim. (2011) New plants records from Midway Atoll, Maui, and Kaho'olawe. Bishop Museum Occasional Papers 110: 23-35.

Sun W., Zhang Z.L., Liu X., Zhang S., He L., Wang G.S. (2012) Terpene glycosides from the roots of Sanguisorba officinalis $L$. and their hemostatic activities. Molecules 17: 7629-7636.

Vaghasiya Y., Dave R., Chanda S. (2011) Phytochemical analysis of some medicinal plants from Western region of India. Res. J. Med. Plants 5: 567-576.

Visentin G.P., Liu C.Y. (2007) Drug-induced thrombocytopenia. Hematol. Oncol. Clin. North Am. 21: 685-696.

Warkentin T.E. (2006) Think of HIT. Hematology Am. Soc. Hematol. Educ. Program 2006: 408-414. 
Warkentin T.E., Markris M., Jay R.M., Kelton J.G. (2008) $A$ spontaneous prothrombotic disorder resembling heparininduced thrombocytopenia. Am. J. Med. 121: 632-636.

Watson H., Davidson S., Keeling D. (2012) Guidelines on the diagnosis and management of heparin-induced thrombocytopenia: second edition. Br. J. Haematol. 159: 528-540.

Xiong Y., Yu Q., Zou J., He Y., Zhang S., Xu R., Yang M. (2014) Protective effects of tannins in Sanguisorbae Radix on myelosuppression mice. Chinese Herbal Med. 6: 222-227.
Zhang L., Gong A.G.W., Riaz K., Deng J.Y., Ho C.M., Lin H.Q., Dong T.T.X., Lee Y.-K., Tsim K.W.K. (2017) A novel combination of four flavonoids from Astragali Radix relieves the symptoms of cyclophosphamide-induced anemic rats. FEBS Open Bio. 7: 318-323. 